\title{
IUELTAL
}

\section{Developing Writing Module for the Fourth-Semester Learners of English Department at State Islamic Institute of Palopo}

\author{
Andi Tenrisanna Syam \\ State Islamic Institue of Palopo \\ e-mail: anditenrisannasyam86@gmail.com
}

\begin{abstract}
:
This research aimed to develop an appropriate module based on the writing needs of the learners. The author took the fourth-semester learners of the English Department at the State Islamic Institute of Palopo in the academic year 2018/2019. The author involved 40 learners as her participants. The method of the research was Research and Development. The author used the ADDIE model. The ADDIE model consisted of five stages, namely analysis, design, develop, implementation and evaluation. The instruments of the research were questionnaires and documents. The data were analyzed quantitatively qualitatively. The results of the content, the design, and the media experts validation showed that the module got good and very good category. The writing I module quality based on the learners' response in the field try-out showed that $75 \%$ of learners very agree and $25 \%$ of learners agree with the materials presented in the module. The result of this research hopefully gives a contribution to some parties, especially to the writing I lecturers and to the other researchers.
\end{abstract}

Keywords: Module, research and development, writing skills

\section{Introduction}

Teaching writing is one of the challenging tasks in English as a foreign language. In the English Study Program of State Islamic Institute of Palopo, the lecturers teach writing separately as well as other skills in English. Writing subject is divided into three sections: Writing I, Writing II, and Writing III. The learners must be an expert in writing after studying all of the materials in writing subject. 
Writing is considered a very complex task for teachers and mainly for learners. When the author interviewed some learners, most of the learners face a serious problem to develop their writing skills. Such as they do not know how to express their ideas, use vocabulary and punctuation appropriately, write good sentences, and so on. Learners also feel that they lack sufficient knowledge of the language (Valle, 2012). The learners were good listeners, they could speak well, and they read a text fluently; however, the learners got low scores in writing. Many factors influenced by this condition, the internal factor, as a study held by Kurniasih (2013) found that the linguistics aspect became a difficulty for the learners to write well. It probably comes from the external factor such as the learners' lack of learning motivation (Oktarina et al. 2018), the materials did not follow the learners' needs (Sumarsono et al. 2017), and the learners used general textbooks.

Therefore, the noteworthy point in the learning and teaching activities is the learning tool. Suhadi (2007) stated that some materials, tools, media, clues, and directions to be used in learning activities. Nwike and Catherine (2013) revealed that learning tools could also be defined as teaching aids used in the classroom to achieve the expected objectives. Orlich et al. (2010), the device is a crucial aspect in the education field, and it is one of the components for good quality of education. Based on the descriptions, the preparation of good learning devices is expected to help increase education quality.

A teacher has a significant role in the learning process. All of the teacher's activity is looked at by learners. How the way a teacher deliver the materials, etc. The teacher has to be creative to make the learners interested in the learning process. There are many solutions to overcome the problems faced by learners. The teacher must find a different way to teach the learners in the class, and teaching writing in English should be supported by using media, one of the media is a module. Amri et al. (2010) revealed that a module is a particular unit of discussion arranged systematically and directed to be used by learners, accompanied by guidelines for their use for teachers operationally. Modules contain material that aims to enable learners to learn independently or with the guidance of teachers in teaching and learning activities and ways to evaluate which is designed systematically and interestingly to achieve the competencies and learning goals (Anjar, 2019). Donelly and Fitzmaurice (2005) wrote that in designing a module, there is a need for a planned integrated approach to the process with a focus on students' learning. They suggest that academic staff can begin the process not by focusing on the content of the module and how they intend to teach it, instead of by focusing on the learning quality that can be acquired by their learners.

Some scholars have developed a writing module, such as Suputra (2010), Emotin-Bucjan (2011), Nardo and Hufana (2014) developed autonomous learning among learners by doing technical writing modules. The authors did modules based on needs such as special techniques in technical writing, constructing verbal to non-verbal data, writing conclusions from research findings, writing recommendations for research, stating research problems, among others. The author evaluated module II in addition to that subject matter, vocabulary and grammar, task, description, and physical make-up.

Murugiah (2013) found that the use of the creative writing module has helped the learners to use a wide range of vocabulary and exciting phrases in continuous writing. Learners demonstrated good use of the ideas that were taught through the creative writing 
module, which were complemented with explicit teaching strategies. Khasanah et al. (2015) produced a module for learning writing exposition text.

Based on the explanation above the objective of the research is to develop an appropriate module based on the writing needs of the learners and the syllabus used in IAIN Palopo.

\section{Literature Review}

\subsection{The Nature of Writing}

Nordquist (2019) stated that writing is an activity where someone composes words and sentences to produce a coherent and purposeful work. Oshima and Hogue (2007: 2) argued that writing is a continual activity. It means after we begin to jot down one thing, we have already been thinking about the idea that we are going to write in our composition. So, writing is an activity in composing sentences becomes paragraph as an expression of our thought.

\subsection{The Definition of Module}

Sweet (2019) discovered that in education, the term "module" refers to an associate tutorial chapter that focuses on a specific topic. Though the main points and activities vary in keeping with the precise context, like course and learners level, most academic modules embody data concerning the subject, target learners-centred learning activities, and culminate in a very project for learners to demonstrate understanding.

\subsection{The Benefits of Using Module in Learning Writing}

Cruickshank et al. in Nardo and Hufana (2014), the utilization of modules is an alternate tutorial style for the educational and satisfaction of the learners. The learners work on their own, and also the teacher's role is to guide and monitor the progress of the learners in doing their tasks. With the utilization of the modules, learners work on varied activities that are grabbing attention and challenging enough to keep up focus and spotlight.

Nardo and Hufana (2014) revealed that the utilization of modules additionally enlarges self-contained study. It directs learners to observe or execute info. To realize the ideas exercise given following the progression of activities from simple to complicate. The arrangement of the exercise intrinsically formalizes the extent of the issue that the learners will perform. Another advantage of victimization modules for instruction is that the acquisition of a much better self-study or learning skills among learners participate themselves in learning concepts presented in the module. They develop a sense of responsibility in accomplishing the tasks provided in the module. The teacher does not help or support; however, the learners evolve independently.

\section{Research Methodology}

The author applied research and development. The design model in this development research was the ADDIE model that consisted of five components, namely analysis, design, development, implementation, and evaluation. It emerged in the 1990-year developed by Reiser and Mollenda. One of the functions of ADDIE is to be a guideline in building the device and infrastructure of training programs that are effective, dynamic, and support the performance of the training itself. 
This model was chosen because the ADDIE model is often used to describe a systematic approach to instructional development. Besides, the ADDIE model is a general and suitable learning model used for development research. The term is almost identical to the instructional system development. When used in the development, this process is considered sequential but also interactive, where the evaluation results of each stage can bring the development of learning to the previous stage. The result of a stage is the initial product for the next stage.

\subsection{Population and Sample}

The population of this research was the fourth-semester learners of English Department at State Islamic Institute of Palopo in the academic year 2018/2019. The author chose 40 learners to be representative of the population. The author chose these learners after the author was aware that they have limited vocabulary and impressive words in their essays so that the author aimed to increase their writing skills. Writing I subject ended for about 100 minutes every week.

\subsection{Instruments}

The questionnaire was given to know the learners' needs in learning writing. Then questionnaires were distributed to the experts and the learners who were involved in the field try out. Questionnaire validation from the experts used to collect data about the content, the design, and the media developed. The author developed questionnaires in the form of a Likert Scale by using five choices, namely agree, strongly agree, neither, disagree, and strongly disagree.

\subsection{Data Analysis Procedures}

The data obtained from the need analysis questionnaire, expert validation form, and tryout questionnaire calculated in a percentage. Furthermore, the result of validation from the experts and try-out held to revise the module to obtain better products.

\section{Findings}

\subsection{The Results of Expert's Judgment on Content}

After the first draft of the material has composed, the next process was expert judgment. Here, the developer asked for the assessment of all chapters from the content experts. The assessment items the cover content, language, materials presentation, and layout of the module itself. The results of expert judgment in each chapter were elaborated below:

The first judgment given to this first chapter was related to the appropriateness of the content of the material. The following table was the result of the expert judgment process:

Table: 1 Average score by expert of content on every aspect

\begin{tabular}{|c|c|c|}
\hline Items & Means & Description of Agreement \\
\hline The appropriateness of the module & 4.5 & Strongly Agree \\
\hline The depth of the module & 4 & Agree \\
\hline The accuracy of the module & 4.5 & Strongly Agree \\
\hline The novelty of the module & 4 & Agree \\
\hline
\end{tabular}




\begin{tabular}{|c|c|c|}
\hline $\begin{array}{c}\text { The language used was appropriate with } \\
\text { learners' ability }\end{array}$ & 4 & Agree \\
\hline The communicative aspects & 4 & Agree \\
\hline The accuracy of the language & 4 & Agree \\
\hline The presentation technique & 3.6 & Agree \\
\hline The task presentation & 3.9 & Agree \\
\hline
\end{tabular}

Based on the expert judgment result above, the appropriateness, depth, accuracy, and novelty of the module got an average score of around 4. While the average score for the language used, communicative aspects, and the accuracy were 4 . It means that the appropriateness of the language, the communicative aspect, and the accuracy was quite good. For the presentation of the material, the average score was 3.9, and the presentation of the task was 3.6. So for this aspect, the presentation of the material was good enough.

\subsection{The Result of Expert's Judgment on Design}

The second assessment item in each chapter was the design, which included the layout, illustration, and typography of the material, as presented in the following table:

Table: 2 Average score by expert of design on every aspect

\begin{tabular}{|c|c|c|}
\hline Items & Mean & Description of Agreement \\
\hline Layout of the material & 4 & Agree \\
\hline Illustration of the material & 4 & Agree \\
\hline Typography of the material & 4 & Agree \\
\hline
\end{tabular}

Based on the result of expert judgment on the design of the material, the average score for each criterion was 4. It means that the layout, illustration, and typography of the material in each chapter were quite good.

\subsection{The Result of Expert's Judgment on Media}

The last assessment item in each chapter was the eligibility of the students' module, which included the design aspects of the display, the aspect of picture quality, the aspect of the appearance, and the aspect of completeness of the component.

Table: 3 Average score by expert of media on every aspect

\begin{tabular}{|c|c|c|}
\hline Items & Mean & Description of Agreement \\
\hline The design aspects of the display & 3.7 & Agree \\
\hline The aspect of picture quality & 3.9 & Agree \\
\hline The aspect of the appearance & 4 & Agree \\
\hline $\begin{array}{c}\text { The aspect of completeness of the } \\
\text { component }\end{array}$ & 4 & Agree \\
\hline The aspects of font usage & 4.3 & Agree \\
\hline The aspect of layout & 4.1 & Strongly Agree \\
\hline
\end{tabular}

Based on the results of these assessments, the learners' module quality on its media was claimed by the experts as good enough. From the results of the expert judgment process in each chapter, the author concluded that the content, design, and media in each chapter were appropriate for the learners of the English department. Based on these assessment results, the design of the students' module quality was claimed by the experts as "valid"; however, there were still a lot of mistakes in the exercise which had to be revised to make the module better. 


\subsection{Field Try-out}

Field try-out held on 30 students in a different classroom. The author conducted a field trial to know the learners' opinions toward the module. In this phase, the author gave the module as learning materials. After using this module, the students answered a questionnaire to assess the module. The questionnaire consisted of 15 statements based on a 1 to 5 scale. Then, the result of the questionnaire was used by the author to evaluate the material draft. The author developed 15 questions in the form of a Likert Scale by using five options, namely agree, strongly agree, neither, disagree, and strongly disagree.

The learners' response to the writing I module showed that $75 \%$ of learners strongly agree, and $25 \%$ of learners agreed with the materials presented. The instruction on the module can understand by the learners. $35 \%$ of learners agree, and $65 \%$ of learners strongly agree, but the learners gave suggestions to make the instructions clearer on task 5 in chapter 3 . The variant of the color was interested. $25 \%$ of learners agree, and $75 \%$ of learners strongly agree. The next statement was the appropriate language was easy to understand based on the learners' respond with a percentage of 15\% learners who did not agree, $20 \%$ of learners agree, and $65 \%$ of learners strongly agree. The learners stated that the diction in chapter 5 was uncomplicated than the diction in chapter 6 . The intermezzo used quotes, and $100 \%$ of learners agree that the quotes were interesting and motivating. The last statement was the appearance of the module interesting for the leaners, with a percentage of $25 \%$ of learners agree, and $75 \%$ of learners strongly agree.

\subsection{Evaluation}

\subsubsection{The Result of Expert's Judgment on Content}

The results of expert judgment in each chapter were not different from the phase of validation on the development stage. The first assessment item was the appropriateness of the content, as shown in the following table:

Table: 4 Average score by expert of content on every aspect

\begin{tabular}{|c|c|c|}
\hline Items & Means & Description of Agreement \\
\hline The appropriateness of the module & 4 & Agree \\
\hline The depth of the module & 4.2 & Agree \\
\hline The accuracy of the module & 4 & Agree \\
\hline The novelty of the module & 4 & Agree \\
\hline $\begin{array}{c}\text { The language used was appropriate with } \\
\text { learners' ability }\end{array}$ & 4.8 & Agree \\
\hline The communicative aspects & 4 & Agree \\
\hline The accuracy of the language & 4 & Agree \\
\hline The presentation technique & 4.5 & Strongly Agree \\
\hline The task presentation & 3.8 & Agree \\
\hline
\end{tabular}

The average score for the appropriateness of the module was 4.8 , the average score for the depth of the module was 4.2, and the average scores for accuracy and novelty of the module were 4. Meanwhile, the language used and the presentation technique got the highest average score. The communicative aspects and language accuracy got the same average score, and the task presentation average score was 3.8. It means that the contents in the modules were apprehensible for the learners. This finding is in line with 
Kurniasih and Rahmawati (2018), the experts confessed that the learning targets of the created materials were clear and in line with the learning targets written in the syllabus. The materials contain diverse and attractive tasks that assist learners in increasing their writing skills.

Nado and Hufana (2013) stated that the learners' activities in language lessons ought to be genuine and meaningful. Language materials ought to be contextualized: rather than separating or making discrete bits of language and materials must be introduced in a significant setting. Richards (2001) argued that material supplies the fundamental for the subject matter, the stability of skills educated, and the types of language rehearsal learners partake; therefore, it is principal to present compatible material for the learners.

The author has revised the writing I module based on the suggestion of the content expert. The expert's comments are: 1) adding an acknowledgement, (2) adding a table of content, (3) adding a glossary, (4) there are some misspellings at chapter 3 , and (5) adding some learning materials related to kinds of paragraphs.

\subsubsection{The Result of Expert's Judgment on Design}

The table below showed the expert's judgment results towards the module design:

Table: 5 Average score rate by expert of content on every aspect

\begin{tabular}{|c|c|c|}
\hline Items & Means & Description of Agreement \\
\hline The layout of the content & 4.25 & Agree \\
\hline The illustration of the content & 3.80 & Agree \\
\hline The typography of the material & 4.80 & Strongly Agree \\
\hline
\end{tabular}

The average score for the layout was 4.25 , the average score for illustration of the content was 3.80 , and the typography of the material was 4.80 . It means that the layout of the material was good and appropriate for the learners of the writing I course. This finding is in line with Anwari (2017) and Supriyadi (2013), the expert claimed that the material layout is easy to perceive, and the author showed suitability in doing layout.

The author has revised the writing I module based on the design expert's suggestion. The expert's comments are: (1) minimizing the size of the pictures, (2) the font and font size should be consistent, and (3) column should not be colored, using white color is better.

\subsubsection{The Result of Expert's Judgment on Media}

The last assessment item in each chapter was the eligibility of the students' module, which included the design aspects of the display, the aspect of picture quality, the aspect of the appearance, and the aspect of completeness of the component.

Table: 6 Average score rate by expert of content on every aspect

\begin{tabular}{|c|c|c|}
\hline Items & Mean & Description of Agreement \\
\hline The design aspects of the display & 4.5 & Agree \\
\hline The aspect of picture quality & 4.6 & Agree \\
\hline The aspect of the appearance & 4.3 & Strongly Agree \\
\hline $\begin{array}{c}\text { The aspect of completeness of the } \\
\text { component }\end{array}$ & 4.7 & Strongly Agree \\
\hline The aspects of font usage & 4.8 & Strongly Agree \\
\hline The aspect of layout & 4.6 & \\
\hline
\end{tabular}


Based on the results of assessments, the quality of the writing I module on its media stated as very good. This finding is in line with Anwari (2017) revealed that expert validator claimed that the appearance of the material is enticing enough.

From the results of the expert judgment process in each chapter, the author concluded that the content, design, and media in each chapter were good and appropriate for the learners of the English department. This module claimed as good because the author designed it with the appearance of image, color, illustration, and an attractive layout that motivates the learners to learn, and each chapter within the module begun with a cloze test where learners provided with ideas and contents supported specific themes. They are required to fill within the blanks with the words provided. Fauzy et al. (2018) claimed that it enhances learners' reading and writing without torturing the learners with things on the far side of their ability. It conjointly recognized that instigating a chapter with a cloze test may facilitate them. They are ready with the context for ideas, exposed to English sentence structures that ease them to develop familiarity with the language and cut back mother tongue interference.

This module also fulfills factors that can help learners in studying and in connecting their study to their basic knowledge and experience. Butcher et al. (2006) stated that the module becomes a resource necessary for the exercise, there are processing activities where the learners get the opportunity to share and practice ideas and notions as they saw and application activities where they get opportunities to expand and enlarge comprehension by being challenged.

\section{Discussion}

This study focused on developing writing I module for the English department learners at State Islamic Institute of Palopo. The first stage of this study was needed analysis in which the purpose of this step was to specify the goal of learners in learning writing. The author divided the process of needs analysis into target needs, which belong to what the learners need to do in the target situation and learning needs, which belong to the knowledge and abilities that learners will require to be able to perform the requisite degree of competence in the target situation.

The results of needs analyses showed that the learners' purpose of learning writing 1 was to make them explore their writing even in formal or informal writing. The competence of the learners was still at the intermediate level. The results of the need analysis are in line with Sumarsono et al. (2017) mentioned that $82 \%$ of leaners wanted to improve their grammar and vocabulary mastery. Compatible with Sundari et al. (2018) wrote that the learners felt difficult in arranging the sentences well. In line with Hendarawaty et al. (2018) stressed that the learners' achievement in writing was low because they did not master the usage of capitalization and punctuation. Furthermore, learners needed to use printing media such as modules presented in colorful and have intermezzo such quotes on one page in every chapter.

The next stage is designing. In this step, the author collected data associated with the development of the learners' modules namely she collected books and sources on the writing, she designed the basic outline of the learners' modules, and she drew up the assessment sheet of the product. The data were collected in the form of a syllabus and 
learning implementation plan. The syllabus and learning implementation plan are developed further as a guide for arranging the teaching materials to be loaded in the development product.

The next stage is developing the product. In this step, the author develops the product through several steps, namely (1) compiling the learners' module based on the syllabus, (2) arranging the materials, (3) determining the assessment rubric, and (4) concerning the structure of the learning' worksheet including the title of the module, the standard of competence, the basis of competence, learning indicators, learning objectives, and tasks.

After the author wrote the product, the next step was the expert judgment process. Here, the module that had been developed by the author has reviewed by three experts. The content expert did the first validation. In this process, the expert conducted an assessment of the questionnaires. Content expert's questionnaire consisted of three items as content appropriateness, language appropriateness, and writing module presentation.

In the validation process, the design expert assessed the questionnaire that has been prepared by the author. Design expert's questionnaire consisted of three items: the layout of the content, the illustration of the content, and the typography of the material.

In the validation process of media, experts assessed the questionnaire that has been prepared by the author. Media expert's questionnaire consisted of six items: the design aspect of the display, the aspect of picture quality, the aspect of the appearance, the aspect of completeness of the component, the aspect of font usage, and the aspect of the layout.

The next stage was the implementation of the product. In this stage, the module based on the experts' assessment has to be tried out. The try-out held to know the learners' module quality. The try-out held in one stage only, namely field try-out. Woken (n.d), pilot test, or try out often provides the researcher with thoughts, approaches, and cues the researcher may not have predicted before carrying out the pilot test. These thoughts and signs improve the opportunities of obtaining clear findings in primary research.

The last stage was evaluation. The evaluation was done by the author to accumulate data on the phases of the learners' module. Based on the experts' validation and learners' response in field try-out, the module was good to be used in teaching and learning writing I subject. The result of this study was supported by Suputra (2010), who found writing materials that have been developed by him are suitable for curriculum and good materials criteria.

Appropriate with the author's finding, Emotin-Bucjan (2011), Khasanah et al. (2015), Kurniasih, and Rahmawati (2018) found that the developed materials in their module contain various and attractive tasks that assist learners in improving their writing skill.

The limitation of this study is in line with Erfiani, Ngadiso, and Suparno (2019), the author has limited time to research so that the author collected the data from one class only. Moreover, module development costs are expensive, a trial of this module is only in one campus, and just a few of students involved in the study. 


\section{Conclusion}

To develop the writing I module, the author used the ADDIE model. The steps in the ADDIE model are analyzing the learners' needs, designing, developing, implementing, and evaluating the module. The results of the content, the design, and the media experts validation showed that the module got good and very good category. The writing I module quality based on the learners' response in the field try-out showed that $75 \%$ of learners very agree and $25 \%$ of learners agree with the materials presented in the module. The result of this research hopefully gives a contribution to some parties, especially to the writing I lecturers and to the other researchers. Writing I lecturers should try to develop writing I learning media in teaching which appropriates to learners' need, especially for writing. In developing an English learning material, lecturers are suggested to refer to the research findings of the characteristics of appropriate English learning materials.

Other researchers are expected to be able to develop an English learning material, especially for writing for different study programs that have problems with the availability of appropriate English learning materials. They are also expected to find the other characteristics of proper learning materials based on the needs of the learners, especially in designing writing I module. For the next researchers, the field try-out should not be conducted in one campus and one classroom; however, the field try-out should be held in more than one campus and more than one classroom.

\section{References}

Amri, S., et.al. (2010). Kontruksi Pengembangan Pembelajaran. Jakarta: Prestasi Pustaka.

Anjar. (2019). Modul: Pengertian, Karakteristik dan Tujuan Pembuatan Serta KomponenKomponennya. Retrieved on 17 July 2019, from http://www.wawasanpendidikan.com.

Anwari, H. (2017). Developing Writing Materials for Deaf Students. Edulite: Journal of English Education, Literature and Culture, 2(2), 2017.

Butcher, C. Davis, C. \& Highton, M. (2006). Designing Learning: from Module Outline to Effective Teaching. New York. Routledge Taylor and Francis Group.

Donnelly, R. \& Fitzmaurice, M. (2005). Designing Modules for Learning. Retrieved on 18 July 2019, from http://arrow.dit.ie/cgi/viewcontent.cgi?article $=1004 \&$ context=ltcbk.

Emotin-Bucjan, M.D. (2011). Development and Validation of Modules in English 2: Writing in the Discipline. JPAIR Multidisciplinary Research, 6(1), 2011.

Erfiani, N.N. Ngadiso, \& Suparno. (2019). Developing supplementary reading materials for Grade 11 students at a Multimedia Study Program. Studies in English Language and Education, 6(1), 13-25.

Fauzy, T. N. L. Bt. T. M., Rosly, R.B. et al. (2018). Evaluating English Module: Guidance to Help Develop Ideas for Writing. European Journal of Education, 1(2), 2018.

Hendrawaty, N. Febriyanti, R.H. \& Sundari, H. (2018). Pengembangan materi ajar berbasis kompetensi untuk mata kuliah Writing 1. Faktor Jurnal Ilmiah Kependidikan Vol. 5 No. 3, 2018.

Khasanah, N., Herpratiwi, \& Sudirman. (2015). Pengembangan Modul Menulis Bahasa Inggris Kelas XI Sekolah Menengah Atas di Kabupaten Pringsewu. Jurnal Teknologi 
Informasi Komunikasi Pendidikan, 3(2), 2015.

Kurniasih \& Rahmawati, H. (2018). Developing Writing Materials Based on Eclectic Approach for Indonesian EFL Learners. Metathesis, Vol. 2, No. 1, 2018.

Kurniasih. (2013). EFL Writing Anxiety: Level, Types, and Causes. Malang: Maulana Malik Ibrahim State Islamic University of Malang in cooperation with Naila Pustake Inc.

Murugiah, M. R. (2013). Improving the 5 th Formers' Continuous Writing Skills through the Creative Writing Module. Advances in Language and Literary Studies, 4(2), p. 7-12.

Nardo, Ma. T. B. \& Hufana, E. R. (2014). Development and Evaluation of Modules in Technical Writing. American Journal of Educational Research. Vol. 2, No. 6, 341-350.

Nordquist, R. (2019). Definition, Examples, and Observations on Writing. Retrieved on 20 May, 2020, from https://www.thoughtco.com/writing-definition-1692616.

Nwike, M. \& Onyejegbu, C. (2013). Effects of use of instructional materials on student's cognitive achievement in agricultural science. Journal of Educational and Social Research, 3(5), 103-107, 2013.

Oktarina, S. Emzir, \& Rafli, Z. (2018). Students' and lecturers' perception on academic writing instruction. English Review: Journal of English Education, 6(2), 69-76. doi: 10.25134/erjee.v6i2.1256.

Orlich, D.C, Harder, R.J. Callahan, R.C. Trevisan, M.S. \& Brown, A.H. (2010). Teaching Strategies: A Guide to Effective Instruction (gth edition). Boston: Wadsworth Cengage Learning.

Oshima, Alice. \& Hogue, A. (2007). Introduction to Academic Writing (3 ${ }^{\text {rd }}$ Edition). New York: Pearson Education, Inc.

Richards, J. C. (2001). Curriculum Development in Language Teaching. Cambridge: Cambridge University Press.

Ristanti, S., et al. (2016). A Study on the Ability in Listening Comprehension on Descriptive Text by the 2nd Semester Students of English Study Program FKIP-UR JOM, 3(1), 2016

Suhadi. (2007). Penyusunan Perangkat Pembelajaran dalam Kegiatan Lesson Study. Retrieved on 23 April, 2019, from http://suhadinet.wrdpress.com/ 2008/05/28/penyusunan-perangkatperangkat-pembelajaran-dalam kegiatanlesson-study.

Sumarsono, D. Bagis, A. K. \& Arrafii, M. A. (2017). Students Needs to Develop English $\begin{array}{llll}\text { Writing } \quad \text { Materials. } \quad \text { Lingua } & \text { 67) }\end{array}$ http://dx.doi.org/10.21512/lc.v11i2.1504.

Sundari, W. Husein, R. \& Rika. (2018) Developing English writing materials of descriptive text for tenth grade student based on project-based learning at SMA swasta Marisi Medan. Genre Journal of Applied Linguistics of FBS Unimed, 7(4).

Supriyadi. (2013). Developing Teaching Material of Writing Scientific Paper Using Constructivism Approach. Journal of Education and Practice (Online) www.iiste.org 4 (24).

Suputra, P.E.D. (2010). Developing English Writing Materials for the Seventh Year Students of SMP Negeri 2 Singaraja, Bali in the Academic Year 2009/2010: A Descriptive Qualitative Research and Development. Retrieved on $20^{\text {th }}$ July, 2020 from 
Andi Tenrisanna Syam

https://media.neliti.com/media/publications/97534-EN-developing-english-writingmaterials-for.pdf

Sweet, K. (2019). What Is an Educational Module? Retrieved on 18 July, 2019, from: http://classroom.synonym.com/format-lesson-plan-7846539.html.

Valle, Y.B. (2012). Developing Writing Skills in English as a Foreign Language. Some Practical Teaching Ideas. Retrieved on 10 April, 2019, from http://www.gestiopolis.com/developing-writing-skills-in-english-as-foreignlanguage

Woken, M. D. (n.d.) Advantages of a Pilot Study. Retrieved from http://www.uis.edu/ctl/wp-content/uploads/sites/76/2013/03/ctlths7.pdf 